\title{
Maritime-Agricultural Communities: Leadership and Independence System of Javanese Village Communities in the Past
}

\author{
Sutejo K. Widodo* \\ Department of History, Faculty of Humanities, Diponegoro University, Semarang - Indonesia
}

\begin{abstract}
This study discusses the leadership and the independence system of Javanese villages in the Past. In maritime village communities - agrarian, there are people who are trusted to lead, with the dynamics of independence. The village naturally regulates its own community based on village bound. The village burden is related to the demands of interests originating from the colonial supra village, forcing the village to be burdened with the interests of supplying goods for the needs of the world market by intensifying feudal housing. This topic is relevant to the village funding program, empowerment of rural communities with substantial funds, but in the implementation, it is still half-hearted because there is no complete belief that the village has actually been proven capable of taking care of itself and meeting its own needs. To discuss this problem, the historical method is used by reviewing important books specifically discussing villages. The results of the study provide evidence that maritime agrarian villages in Java already have leadership independence that practices in managing and meeting among the villagers. Thus, it is undoubted about the ability to channeling the village funds.
\end{abstract}

Keywords: Maritime-Agricultural Communities; Leadership System; Independence System; Javanese Village.

\section{Introduction}

Leadership System and Independence System of Javanese Village Communities in the Past are chosen as past events containing topics discussing village leadership and independence. The discussion is focused on groups of people gathered in a joint bond called village community. Those groups had trusted persons and chosen as leaders, thus in their long history; villages grew and developed along with their dynamics of independence. Villages were naturally formed by their freedom to regulate their own communities based on village bond. It was as a result of their relationship with external activities and their adaptation to village needs, related to supra village interests based on feudal bond. Village burden related to demands of interests from supra village in a long

* Corresponding author: sutejokw@lecturer.undip.ac.id 
period as a result of colonial pressure, had forced the villages to bear the burden of the interests of supplying goods for needs of world market by intensifying feudal slavery mainly in Java.

This topic is relevant to massive resonance of village fund program, a village community empowerment equipped with substantial funds, even though its implementation is still half-heartedly since there is no full trust that that the villages are proven to able to take care themselves and fulfill their own needs. The villages as an original concept of Indonesia had soul, spirit, effects of Hindu, Islam, Colonial who came and later enriched village repertoire, but these factors did not change their original character. Enthusiasm and spirit of the village bond during the short Japanese occupation was maximized as center of a very supportive movement on struggle for independence. Using a special literature sources discussing villages, mainly from the writings of G. Gonggrijp, D.H. Burger, and Soetardjo Hadikoesoemo, as important works, this paper is based on those literature sources.

\section{Results and Discussion}

\subsection{Village Independence and Village Leadership}

The current villages are the results of long process of human struggle in organizing life together in a group called the communities. Growing process of community village explanation has three main reasons: first to live, second to maintain their lives, and third to achieve progress. Therefore, villages grow based on their main types of activity. The most common village is Agriculture Village. According to Kartohadikoesoemo [1], Agricultural Village is formed by a group of people who clear grove of trees and work on the empty land alone or in a group to plant and produce food ingredients. The better the cleared land for agriculture, then more people will join to form a place to live. Good and fertile land facilitates people to fulfill their needs, and even they are able to produce more; mainly in valley area where there is a growing large group of people with a large population. By the ease of food producing and exceeding the needs, this situation will allow an opportunity to develop their potential [1].

Likewise, it happens also in Fishing and Shipping Villages. In areas that produce a lot of fish, which can be traded to others; villages are formed by fishers or sailors, or people whose work transport goods across the sea. The similar can also be seen in villages developing on the banks of large rivers. These all the process of the occurrence of fishing and shipping villages on the banks of sea and large rivers.

Market (trading) Village, is a market where people from various places can meet one another to sell and buy goods produced by surrounding community. Near the market, along with the time, there is a growing community of people whose jobs are buying and selling needed goods elsewhere. Therefore, a trading village is formed. Likewise, it also occurs to the formation of Mining (Tambangan) Village, Sacred (Keramat) Village, and Fishpond (Tambakan) Village as well as other village forms, they have a process based on types of work of people inhabiting the villages.

A true village grew based on a deep inner bond among each member of the communities, that, it was an inseparable part of a loved community and for whom they were willing to sacrifice all the interests any time: sense of each member of loved community. Therefore, one another bore the responsibility upon the safety and well-being [1].

Villages that grew with an inner bond among their people needed a tool to continue their life. To establish their life together, they required procedures or rules of order. So, to make the community members always obeyed the procedures, it was needed someone who 
supervised, and gave correction when there was a violation. Therefore, the communities appointed one of their trusted persons to conduct the task. The trusted person also became the community representative, if a relationship between that community and others needed to be made for the sake of mutual interest or a party interest. Therefore, it was born a position of "head of community" which was usually regarded as the foremost and oldest among community members [1]. Due to the appointment and duties of community head, it was clear that the Village Head authority was only as "community representative" and it did not have the role as a complementary tool for autocracy that ruled community; legitimate rules and obligations were only those based on decisions made in the communities in a Village Meeting. Therefore, the position, of which during Dutch colonial it was given to Village Head, as if it was the only one in charge in village administration, while, Village Meeting among the important matters it was only solely "heard", this fact was in contrast to applicable original law (customary law). The Customary Law did not recognize a position of a head as an autocrat. The Colonial gave a power as an autocrat to Village Head as a distraction to make them rule the community easily. Soetardjo Katohadikoesoemo's notes provided basic concept that in its nature the villagers appointed Village Head to represent village interests from customary Village Meetings within village bound frame. It happened until the era when villages in Java received Hindu effects. This description was based more on the perspective of customary law and tradition stating that Village Head in their position was not part of autocracy, but rather as a community representative.

\subsection{Burden of Feudal Bonds and Village Leadership after Hindu Effects}

Villages have strategic meanings and importance. It is viewed from an economic point of view, as stated by Gonggrijp in Schets Enner Economische Geschedenis van NederlandchIndie that Indonesian people economic life is characterized by village life. It can be stated that anyone who knows a village life has a key to understand Indonesian people and their destiny. He further states that Indonesian Economic History is determined by seven important factors. The first factor is nature: its location to other countries and on the edge of the big world trade, entrance, climate, fertility and income, wealth of natural resources. The most important factor for Indonesia is its location flanked by two oceans and in Malacca Strait which connects the two oceans, and also lies between two ancient cultures namely India and China.

The second factor is the ideals possessed by Indonesian people. The third is foreign nation's wishes. The fourth is population density. The fifth is possessed expertise. The sixth is capital formation, and the seventh is world economic events. Indonesian Economic History indicates a remaining basic motive behind economic changes, which last forever; that is, a small and simple community that remains at the core of all changes that have taken place over centuries in Indonesia.

It is further stated that villages were small and underdeveloped communities in the past, mostly inhabited by farmers who acted as members of a large family in various ways. Their social life moved within village boundaries. Their interests were also village interests and vice versa. Their horizons were not further than their village area. Their common needs, such as food, clothing, housing, security, justice, trust and others, could largely be fulfilled by working in village territorial boundaries, both individual and mutual. Only certain needs such as salt, iron, tools or weapons, jewelry or weaving materials that could not be obtained from the village itself, therefore it is required "in natura" exchange or trade with outside world. In other words, Indonesian people were mainly engaged in "closed village households". The word "closed" did not mean absolutely closed, but it had the meaning without meaningful exchange of traffic, and the production belonged to own consumption not for market. Therefore, "national household" of Indonesia at the beginning of its history, which was 
roughly in the beginning of Christian era, could be regarded as a collection of "in natura" closed village households.

Indonesian village households were small and weak communities. Custom controlled human behavior. Such a life might be regarded as not giving a chance for strong personality. According to Gonggrijp, communal system had become a barrier of growth towards strength and prosperity. As a result, people relied on each other. In a small agrarian community, prosperity did not occur under constant way, it depended on harvest success. It occurred because the members did not have a stimulus to produce beyond their own needs until the following harvest, therefore, this condition did not provide possibility of a significant capital production.

However, village development level in each region could not be compared each other. Java island, experienced more development than other islands of Indonesia. Before the arrival of Hindu effect, Javanese had skills on metal processing, navigation, astronomy, and rice fields.

These simple households were later affected by Hindu civilization. As a result, native Indonesian people were shrouded under royal power over village households. The most important Hindu effect was king's power for Indonesian economic life. The biggest and most important change as a result of Hindu arrival was that villages had to fulfill their own needs, so, after king's power, except for producing for one's own needs, the village had to fulfill king's needs alongside the vassals and his soldiers [2].

King's power was despotic. According to Hinduism, the king had the right over life and his people. The despotic nature was strengthened by caste system in Java, and hardened by the principle of Sivaism to worship the king as an incarnation of Gods. In that community, people prosperity was depending very much on king's personality. Considering that the traffic was very limited, then, far jurisdiction was given to vassals, who were not far from the king. Throughout Hindu period, despotic traits became stronger and peaked. According to Krom, Majapahit kingdom was based on sea power: the seas and beaches in Indonesia were controlled by Majapahit. If a small kingdom became a conquered area of Majapahit, then, Majapahit government did not interfere their domestic situation. This subdued country had to send envoys at certain times as a sign of submission and take a suitable stance to Majapahit government's will on other Indonesian countries. Parts of this far great empire were sufficiently used as areas of influence. All foreign influences in the kingdom were rejected. The subdued regions were required to pay tribute or surrender money [2]. This was relevant to Negara Kertagama Pupuh 15/3, stating that:

Since the Archipelago received Your Majesty's orders.

They send tribute every season.

Driven by desire to increase happiness.

Poets and employees are ordered to withdraw tribute.

In Indonesia, various signs in the period of 12th to 15th century indicated that Java Sea trade was making great progress. Vleke argued, that Java Sea trade experienced great progress, trade was growing rapidly, and trade progress in the 12th century had a major effect on the development of kingdom of Kediri into a major sea state [3].

Hindu colonization took place peacefully. Java Island was known as a fertile and rich country. Hindu colonization first took place on north coast of Java and then along coast of Malacca Strait which was a traffic lane between India and China.

This period was marked by the construction of temples and royal tombs that could be seen until today. The construction of temples and tombs was not people business, but it was king's affair. Indirectly, the remnants of Hindu Javanese buildings gave a hint that there had been a prosperous level of community life. Likewise, based on Chinese chronicles about a particular 
area in Java, it was stated that the country was rich in fish, birds, livestock, and fruits, and also on country sale and wealth such as rice, turtles, peppers and so on, giving the impression that as if these results existed and people achieved prosperity. However, the sales did not provide an explanation of people's income and property rights. Goods in large quantities and piles up in the city, but on the contrary mass of the population created insufficient needs, not only those who lived in remote area, but also those who lived in coastal areas. This situation was indirectly shown by relics of ancient building art. Only temples and tombs were built using durable materials. Even, royal palace was made of wood; only the foundation and base were made of stones.

When Dutch first arrived in Banten, as the most important trading city at the time, they only found a house inhabited by a Port Master (Shahbandar), made of stone. Therefore, a description of people's prosperity was not immediately clear. Hindu effects became a supporter of a higher level of civilization than the civilizations on the islands where they founded the colony. In its meetings with Indonesian households that lasted for centuries, Hindu effects had brought Indonesian households to a higher level. From foreign businessmen, Indonesians recognized people economic and new needs. Its trade with foreign countries became meaningful, such as with China, even the trade took the form of exchanging gifts among kings. Hindus introduced a number of industrial fields in Indonesia, such as batik, and sugar production (possibly). In other fields of industry, they introduced weaving, and working on metal, Hindus took it to a higher level. Mainly Javanese was richer in elements of their culture. They then understood puppet, gamelan, poetry, mysticism that were centered in the palace. By an improvement among production technique and trade development, then the whole production for villages became greater.

Then with the arrival of Muslims in Indonesia in the XV century, the economic life of Indonesian people did not undergo an essential change: Indonesian households remained agrarian, villages remained united, exchange traffic remained unoccupied. Under the influence of Islamic traders who came from Gujarat and Arab countries, trade between 1400 - 1600 experienced rapid development and for some Indonesian tribes, such as the Moluccans, Javanese who lived in the northern coast city of Java, Malays from several the coastal kingdom, Makassarese and the Buginese trade were significant as well [2].

\subsection{Utilization of Feudal Bonds and Village Leadership during the Colonial Period}

It is interesting to compare the effects of V.O.C on indigenous populations in the two regions of the Indonesian archipelago, namely Java and Maluku. In both parts, the effects of the Colonial's administration on the prosperity of the people were very different. In Java, the consequences could be said to be not too bad; while in Maluku, the prosperity of the people had perished. The difference was due to the inequality between village households in Maluku and village households in Java. Villages in Maluku, especially in the Banda islands, producing for the world market, so that when the monopoly system was implemented by V.O.C, its free trade as a source of prosperity was threatened. Whereas in Java, they performed the production to meet their own needs. It was only a small amount of production used for the world market. The economic interests of the Maluku villages contradicted to the interests of the Colonial's monopoly. In such case, for Java only it concerned small classes in communities: traders in port cities, and farmers of pepper, cotton and some goods that were not so significant. Throughout the two centuries, between 1600 and 1800 , the course of economic history was controlled and determined by two factors: first, the nature, talents and ideals possessed by the Indonesian people, second, the nature, talents and ideals of foreign nations, who always had contact with the Indonesian people [2]. 
In establishing a monopoly, the Colonial faced the interests of merchants from Europeans and Asian peoples. At the beginning of establishing the monopoly, the Colonial in dealing with both Banten kingdom and Mataram kingdom was asked to help fight the Portuguese or with kingdoms from their own nation. As Coen said that trading had to be carried out and maintained under the auspices of the weapons. It was always tried to obtain merchandise, especially cloves at the lowest price. In the early 17 th century, the Colonial could buy 1 bahar ( 600 pounds) of cloves at a price of $\mathrm{f} 120$, sold in Europe f 1,200. Even though supervision had been carried out in Ambon, Uliaster, Seram and Ternate islands, smuggling was inevitable, and to maintain the monopoly it was carried out extirpation of clove trees in Hoalmoal or hipping of Hongi. If the price of cloves was high, clove trees were planted on a large scale, and when the price of cloves was low, the trees were destroyed. With such a policy, Ambonese suffered not only due to monopoly, but also because there was no regular system in carrying out monopolistic politics. Furthermore, the Colonial's salary to employees which was too low, resulting in a difficult choice; in which, there were only two alternatives for them, namely life deprivation or dishonesty. Prosperity in Ambon had decreased with a marked decline in population at the end of the 18th century, a population of less than 100,000 or $2 / 3$ of the early 18 th century. Clove production also fell from $31 / 2$ million to 1 million.

Meanwhile, households in Java in 1600 could be divided into two neighborhoods. First, inland villages that were agrarian with closed villages that produced to meet their own needs, and second; coastal cities along the north coast relying on trade. Although trading activities in Banten were busy, the main actors were Port Master (Syahbandar) and Governor (Patih). There were no general freedom, but the despotic nature of the kingdom, and the lack of proper fulfillment of trade interests. Foreigners occupied important place in major trade; while indigenous people occupied insignificant place. Banten in 1600 had similarities with the Indonesian people before and after this period.

People in the inland of Mataram also faced an unclear situation. Wealth, rice fields, houses, and harvests were not protected. The lack of protection for villagers' property was often illustrated by expressions "nek awan, duweke sang nata, yen bengi, duweke dursila". It means that in a bad situation, there is only one right that cannot be revoked, that is the right to leave the country. In accordance with the severity of the pressure coming from the despotic king, there were two kinds of villages. First, the villages which still showed most of the original characteristics of Indonesian villages; including villages located far from the centers of royal power, and secondly; villages which were very dependent on the king or vice king located in this area of the kingdom. In a village that was very dependent on the vice king; the village head was as an agent of the king who acted to provide satisfaction to the power giver, causing pressure on the citizens.

In extending and running a monopoly, the Colonial with its insignificant power could control Java, but to conquer the small islands in the Moluccas; the Colonial fought against a nation as a force. In Java, the Colonial faced village heads that had been divided, along with their henchmen. The influence of the Colonial outside Maluku and Java was very insignificant. Even the people in Sumatera hardly experienced the monopoly of the Colonial [2]. Nonetheless, the Colonial fell because of running the monopoly too long by giving very low salaries to its employees, and crimes as well as its fraud were the main cause of its collapse.

\subsection{Improvement of Feudal Slavery and Village Leadership}

According to D.H. Burger, the economic conditions in Java around 1800 could be categorized into two types, namely village bond and feudal bonds. Village bond was a sense of brotherhood (horizontal) and a sense of submission to the village head (vertical) was characterized by the simple economic life of the peasant population, which produced goods 
for the immediate gratification of one's own needs. Their needs and modes of production were determined by tradition, such as all village life containing hereditary traits [3]. The economic was on the basis of fulfilling their own needs in a small, low environment, because it only gave the possibility to meet basic living needs and there was no opportunity for high economic development. In the association of life in such a village, the need for economic organization was very small. Those needs were fulfilled mainly by mutual cooperation. Therefore, the organization's tools mainly consisted of village bond in which a sense of brotherhood among the villagers and a sense of submission to their village head. This sense of submission was developed by the opinion of the community, so that the village heads in Central and East Java had the position of king. Therefore, life in the village was a framework of intermittent and non-fragmented relationships [4].

In this simple life, there was regular economic life, which took care of the needs of Indonesian government organizations and the Colonial. These needs were also fulfilled by villagers who leaved the villages. The organizational tool of organized economic life consisted of power relations and obedience arising from the power of kings, regents, officials who were superior to the village. This relationship of power and obedience was called feudal bond in Indonesian communities. The second organizational tool of organized economic life was village bond, because villages were used in the production process. The flow of goods and services was organized by means of feudal and village bonds which together constituted the customary bonds of the Indonesian people. When feudal bond consisted solely of vertical bonds and did not contain communal bonds, it was referred as feudal slavery [3].

As Muntinghe found in his research that villages across the North coast of Java, appointed village heads by "election" by all villagers. Therefore, Raffles made decision that in each village the population had the right to choose its head. The Muntinghe report became the basis for the "Commissatissen Generaal" of the Dutch government to establish a provision as contained in the "Staatsblad" of 1819 No. 13 that the old custom which gave the villagers the right to choose their heads and replace their heads kept applicable. In "staatsblad" 1878 no. 47 and "Staatsblad" 1907 no. 212, the election rules for village heads were renewed and given new conditions, without reducing the freedom of the people to exercise their right to vote freely.

According to an investigation conducted by the Dutch East Indies government, it was later said that the villagers' right to elect the village head was not genuine. This opinion could be said to be half true. As Soetardjo Kartohadikoesoemo argued, that the problem was where the investigation was conducted. In regions, where the government was organized on the basis of the genealogical system, this opinion was correct, because in such areas the head was raised according to the hereditary system. In the Negorogung areas of the Pajang-Mataram kingdom, village heads were appointed by or on behalf of the King, especially in the Norowito area, which was an area that directly produced a variety of crops and livestocks for the benefit of the Palace. Likewise, it also happened in the Perdikan village. However, outside these areas, regions which were prepared on the basis of their own volunteerism as territorial areas, from the ancient times the village heads in these areas were directly elected by residents or villagers. Politics to continue the procedures and customs of the village, and to continue the village head election system had had a good effect, that the village villagers always paid great attention and obeyed the village head.

However, strong inner bond between the people and the village head in colonial times was abused by the colonial government to achieve its own benefits at the expense of the people. The concept of landrente by Raffles and dwangcultuur, which were forcibly planting various kinds of plants needed by the Dutch for the world market, such as tobacco, sugar, tom and so on, could only work by the existence of great inner power on the side of the village head over his people. Although the power of the village head was often misused by the colonial government, but the inner bond between the village head and the people from 
centuries to centuries remained strong. Likewise, what happened in Sumatera, Kalimantan, Sulawesi and other islands was no different.

The Dutch realized that they were right and it was firmly held, but it was abused. Even in the days of Japanese military occupation, which was so short, prominent Japanese military authorities were quickly able to see and understand these factors. Japan not only used the inner power, which was on the side of the village head over his people, for his own interests but also for the interests of the people and the nation of Indonesia so profoundly that the latter interest became a secure basis for giving physical and mental strength to the Indonesian people to regain independence from foreign rule with a resounding result.

It was regrettable that even in this era of independence the above factors were not yet well known by the Central Government which kept changing and was used as well as possible for the interests of the people concerned, the nation and state. In fact, there were prominent people in the government who desired that the village head was not elected by the people but determined by the authority of the Central Government.

There were two opinions as for the disagreement questioning where and since when the village existed. The first opinion from Mr, Van den Berg, said that villages in Java were influenced by Hinduism. It was no doubt that this was the same as in the Indies, village was indeed originally established by the Indies, explained the Professor Kern. The second opinion of Prof. Van Vollenhoven stated that the jurisdiction in Java, Madura, and Bali that village was the creation of native Indonesians, and not a fabrication of people under Hindu influence. This was supported by Prof. J. De Louter, Dr. Brandes, F.A. Liefrinck, Mr. T.C. Lekkerkerker. Therefore, the opinion stating that village was not made by Hindus, but made by the Indonesian people themselves; although it used the Sanskrit name, had advantages to be accepted.

Then, after Islam entered Indonesia, our jurisdiction basic did not change. The people in village to this day still worshiped Village Predecessor Spirit. Villages over the centuries developed into a legal entity, where the common interests of the population according to customary law were protected and developed. The law contains two aspects, first the right to take care of the interests of their own regions (the right to autonomy), the second the right to choose the head of his own village.

However, there are still prominent people in the government saying - just like in the Dutch era - that the people in the village are not mature to receive the right of autonomy. The statement shows that they do not know the village at all and do not understand the meaning of the word "autonomy". From more reasonable literary sources, it is stated that the most experienced in implementing the right to autonomy are actually the people of the village, because before the King's power and foreign powers, the village is fully autonomous. However, the level of material and how to do autonomy is indeed very simple. It is necessary to think about opportunities to give modern autonomy rights to village communities (not regions). The autonomy will run smoothly as long the one who leads at the central area is competent. 


\section{Conclusions}

The community life unit called as village is the original formation of the Indonesian people, which was formed and founded by people who had activities in fulfilling the needs of life or works that were mostly similar, so that agricultural villages, fisheries, market villages and so on were formed. The unity of life was intertwined in village bond, producing with the aim to meet their own needs, and for the sake of sustainability in living together. Community representatives as Village Heads were elected among them. The village after the influx of Hinduism accepted the organization above the village, where the village which originally produced goods and services for its own needs, was added to the production which was intended for the king and the vassal based on feudal bond. During the Colonial period, village bond and feudal bond were also utilized to produce products aimed at meeting the needs of the world market. These bonds were further intensified during the colonial administration for the benefit of the business world. Likewise, the role of the village head had undergone changes and shifts that were increasingly heavy. For the implementation of autonomy, village had a long experience. Therefore, in some cases with certain formulations, the village was felt to be more ready to carry out autonomy through village consultation meetings.

\section{References}

1. S. Hadikoesoemo, Village. (Jakarta: Balai Pustaka, 1984).

2. G. Gonggrijp. Sejarah Ekonomis Indonesia, trans. Dharmono Hardjowidjono, (Jogjakarta: Universitas Gadjahmada, 1967).

3. D. H. Burger. Sedjarah Ekonomis Sosiologis Indonesia I, trans. Prajudi Atmosudirdjo, (Jakarta: Prandnjaparamita, 1962).

4. C. Geertz, Agricultural Involution: The Process of Ecological Change in Indonesia. (Berkeley: California University Press, 1974). 